\title{
PENGARUH PENERAPAN MODEL PEMBELAJARAN PENALARAN DAN PEMECAHAN MASALAH (MP3M) TERHADAP KEMAMPUAN PEMAHAMAN KONSEP MATEMATIKA SISWA KELAS VIII SMP NEGERI 6 SINGARAJA
}

\author{
K.L. Apriliani, I M. Ardana, I G. A. Mahayukti \\ Jurusan Pendidikan Matematika, Universitas Pendidikan Ganesha \\ Singaraja, Indonesia \\ e-mail: k.aprilialinda@gmail.com , ardanaimade@undiksha.ac.id , gustiayumahayukti@undiksha.ac.id
}

\begin{abstract}
Abstrak
Penelitian ini bertujuan untuk mengetahui pengaruh penerapan Model Pembelajaran Penalaran dan Pemecahan Masalah (MP3M) terhadap kemampuan pemahaman konsep matematika siswa. Populasi penelitian ini adalah seluruh siswa kelas VIII non unggulan SMP Negeri 6 Singaraja tahun ajaran 2016/2017 yang berjumlah 293 orang yang tersebar ke dalam 10 kelas. Pengambilan sampel dilakukan dengan teknik cluster random sampling. Sampel pada penelitian ini adalah siswa kelas VIII B9 sebagai kelas kontrol dan VIII B7 sebagai kelas eksperimen. Desain penelitian yang digunakan dalam penelitian ini adalah post test only control group. Data kemampuan pemahaman konsep matematika siswa dikumpulkan menggunakan tes kemampuan pemahaman konsep matematika. Data dianalisis dengan menggunakan uji-t ekor kanan dengan taraf signifikansi $5 \%$. Hasil penelitian menunjukkan bahwa $t_{\text {hitung }}=2,7245$ lebih dari nilai $t_{\text {tabel }}=1,6725$, sehingga $H_{0}$ ditolak. Ini berarti kemampuan pemahaman konsep matematika siswa yang mengikuti pembelajaran dengan Model Pembelajaran Penalaran dan Pemecahan Masalah (MP3M) lebih baik daripada kemampuan pemahaman konsep matematika siswa yang mengikuti pembelajaran konvensional. Dengan demikian, penerapan pembelajaran dengan Model Pembelajaran Penalaran dan Pemecahan Masalah (MP3M) memberikan pengaruh positif terhadap kemampuan pemahaman konsep matematika siswa.
\end{abstract}

Kata kunci: konsep, MP3M, pembelajaran, penalaran

\begin{abstract}
This objective of this research is to investigate the effect of Reasoning and Problem Solving learning model to students' mathematics conceptual understanding. The population consisted of 293 students of eighth unseeded grade students of SMP Negeri 6 Singaraja in the academic year of 2016/2017 which are divided into ten classes. Sampling was done by cluster random sampling technique. Samples in this research were students in eighth B9 class as the control group and eight B7 class as the experimental group. The research used Post Test Only Control Group Design. Data of students' mathematics conceptual understanding were collected by using students' mathematics conceptual understanding test. This data were analyzed by using a onetailed $t$-test with significance level of $5 \%$. The result of data analysis showed that $t_{\text {calculate }}=2,7245$ is more than $t_{\text {table }}=1,6725$, so the null hypotesis is rejected. This means that students' mathematics conceptual understanding who learned through Reasoning and Problem Solving learning model is better than students' mathematics conceptual understanding who learned through conventional learning. Thus, Reasoning and Problem Solving learning model gives positive contribution toward the students' mathematics conceptual understanding.
\end{abstract}

Keywords: concept, learning, reasoning, problem 


\section{PENDAHULUAN}

Pendidikan merupakan salah satu faktor yang sangat menentukan kualitas sumber daya manusia pada suatu bangsa. Tantangan dan tugas dunia pendidikan ini dijawab oleh pemerintah melalui berbagai upaya peningkatan kualitas pendidikan. Upaya ini diataranya adalah menyusun dan menyempurnakan kurikulum pendidikan, peningkatan sarana dan prasarana pendidikan, melaksanakan pedidikan dan pelatihan guru, serta penerapan berbagai pembelajaran inovatif.

Sekolah sebagai salah satu instansi pendidikan merupakan tempat pengembangan ilmu pengetahuan dan teknologi dalam diri siswa sebelum terjun ke masyarakat. Berbagai bidang yang berkaitan dengan pengetahuan dan teknologi dibelajarkan di sekolah, salah satu bidang tersebut adalah mata pelajaran Matematika. Selain sebagai bidang ilmu dalam dunia pendidikan, Matematika juga merupakan salah satu bidang studi yang sangat penting bagi peserta didik maupun bagi pengembangan bidang keilmuan yang lain (Suherman, dkk, 2003). Kedudukan Matematika dalam dunia pendidikan memiliki manfaat yang sangat besar sebagai alat dalam perkembangan pendidikan dan kecerdasan akal. Oleh karena itu, pendidikan dalam bidang Matematika berpotensi memainkan peranan strategis dalam meyiapkan sumber daya manusia yang berkualitas. Potensi ini terwujud apabila pendidikan matematika berhasil menumbuhkan kemampuan berpikir logis, kritis, kreatif, berinisiatif, dan adaptif terhadap perubahan dan pembangunan. Mengingat pentingnya peran matematika dalam kehidupan bermasyarakat maka penguasaan dan kemampuan pemahaman konsep matematika harus dipahami dengan tepat dan benar.

Matematika merupakan mata pelajaran yang dipelajari siswa dari jenjang pendidikan dasar hingga pendidikan menengah. Pendidikan matematika pada jenjang pendidikan dasar merupakan pondasi bagi penguasaan materi Matematika pada jenjang selanjutnya. Oleh karena itu, pada jenjang pendidikan SD dan SMP perlu dibangun pondasi matematika yang kokoh. Penguasaan materi Matematika di SD merupakan pondasi terhadap penguasaan materi Matematika di SMP. Sedangkan penguasaan terhadap materi matematika SMP akan menjadi prasyarat penting untuk mempelajari Matematika pada jenjang pendidikan selanjutnya. Hal ini sesuai dengan standar kompetensi lulusan untuk mata pelajaran Matematika tingkat SMP dalam Permendiknas Nomor 23 Tahun 2006 sebagai berikut.

1. Memahami konsep matematika, menjelaskan keterkaitan antar konsep dan mengaplikasikan konsep atau algoritma, secara luwes, akurat, efisien, dan tepat, dalam pemecahan masalah.

2. Menggunakan penalaran pada pola dan sifat, melakukan manipulasi matematika dalam membuat generalisasi, menyusun bukti, atau menjelaskan gagasan dan pernyataan matematika.

3. Memecahkan masalah yang meliputi keterampilan memahami masalah, merancang model matematika, menyelesaikan model, dan menafsirkan solusi yang diperoleh.

4. Mengkomunikasikan gagasan dengan simbol, tabel, diagram, atau media lain untuk memperjelas keadaan atau masalah.

5. Memiliki sikap menghargai kegunaan matematika dalam kehidupan, yaitu memiliki rasa ingin tahu, perhatian, dan minat dalam mempelajari matematika, serta sikap ulet dan percaya diri dalam pemecahan masalah

(Depdiknas, 2006: 4)

Berdasarkan standar kompetensi lulusan di atas, keberhasilan dalam belajar matematika pada tingkat SMP salah satunya dapat dilihat melalui kemampuan pemahaman konsep. Hal ini didukung oleh suatu pendapat yang dikemukanan oleh Zulkardi (2003: 7) yang menyatakan bahwa "mata pelajaran matematika menekankan pada konsep". Artinya dalam mempelajari matematika peserta didik harus memahami 
konsep matematika terlebih dahulu agar dapat menyelesaikan soal-soal dan mampu mengaplikasikan pembelajaran tersebut dalam kehidupan sehari-hari.

Kemampuan pemahaman konsep matematika mempunyai peranan yang sangat penting untuk mengembangkan pola pikir siswa, namun pada kenyataannya kemampuan pemahaman konsep siswa belum mendapat perhatian yang optimal. Pada pembelajaran di kelas, siswa jarang diberikan kesempatan untuk mengkonstruksi pengetahuaanya sendiri, sehingga siswa mengalami kesulitan memahami dan memaknai apa yang dipelajari. Dalam menyelesaikan soal, siswa cenderung terpaku pada contohcontoh penyelesaian yang diberikan oleh guru, sehingga ketika diberikan variasi soal yang berbeda siswa tidak paham bagaimana menyelesaikan soal tersebut. Kemampuan pemahaman konsep ini merupakan bekal untuk siswa dapat mencapai kemampuan dasar yang lain seperti penalaran, komunikasi, koneksi dan pemecahan masalah.

Para ahli pendidikan telah banyak mengemukakan dan mengenalkan model atau metode pembelajaran untuk lebih mengefektifkan pembelajaran di kelas. Model pembelajaran yang baik digunakan sebagai acuan dalam pembelajaran di kelas sekaligus sebagai tutorial untuk menentukan perangkat-perangkat pembelajaran yang sesuai dengan bahan ajaryang diajarkan (Trianto, 2011). Dalam pembelajaran tidak ada suatu model pembelajaran yang paling baik. Modelmodel pembelajaran yang digunakan tentunya memiliki kelebihan dan kekurangan, dan setiap materi pelajaran memiliki karakteristik tersendiri sehingga tidak semua materi pelajaran bisa disampaikan dengan satu model atau metode pembelajaran tertentu. Pembelajaran yang dapat mengembangkan kemampuan pemahaman konsep matematika siswa adalah pembelajaran matematika menurut pandangan konstruktivis.

Pembelajaran matematika menurut pandangan konstruktivis mengutamakan peran aktif siswa dalam proses pembelajaran. Dengan adanya kebiasaan aktif tersebut, siswa akan memiliki motivasi yang tinggi dalam belajar. Hudoyo (dalam Ardana, 2008 : 4) menyatakan pembelajaran matematika yang menggunakan pandangan konstruktivis dicirikan dengan hal-hal berikut, yaitu (1) siswa terlibat aktif dalam pembelajaran, (2) informasi baru harus dikaitkan dengan informasi lain sehingga menyatu dalam skemata yang dimiliki siswa agar pemahaman terhadap informasi menjadi kompleks, dan (3) orientasi pembelajaran adalah pemecahan masalah.

Urain tersebut di atas lebih meyakinkan bahwa dalam pembelajaran matematika hendaknya memberikan lebih banyak kesempatan kepada siswa untuk terlibat aktif dalam pembelajaran, sehingga siswa dapat mengeksplorasi pengetahuan yang dimiliki yang berakibat pada pemahaman siswa terhadap materi yang sedang dipelajari. Namun pada kenyatannya, pembelajaraan saat ini masih berpusat pada guru, dimana guru masih aktif sebagai pemberi informasi dan mendominasi pembelajaran di kelas, sedangkan peserta didik pasif sebagai penerima informasi, sehingga hal tersebut kurang memberikan kesempatan kepada siswa untuk aktif dan mengeksplorasi pengetahuan yang dimiliki yang menyebabkan pemahaman siswa terhadap materi pembelajaran masih kurang. Kondisi ini diungkapkan pula oleh Hanifah (2016) yang menyatakan siswa kurang terlibat aktif dalam pembelajaran, hanya mendapat pengetahuan dari penjelasan guru dan buku paket yang disarankan sehingga siswa tidak benar-benar paham konsep materi yang dipelajari. Oleh karena itu, diperlukan upaya perbaikan proses pembelajaran di kelas dengan menerapkan pembelajaran yang berpusat pada siswa. Salah satu alternatif pembelajaran dalam pandangan konstruktivis yang dapat mengaktifkan siswa dan mengembangkan kemampuan pemahaman konsep matematika adalah Model Pembelajaran Penalaran dan Pemecahan Masalah, yang selanjutnya disingkat dengan MP3M. Model Pembelajaran Penalaran dan Pemecahan Masalah merupakan salah satu model pembelajaran yang dapat membangkitkan daya nalar siswa sehingga kreativitas 
berpikir mereka berkembang yang pada akhirnya siswa terlatih untuk berpikir secara logis, kritis, dan kreatif (Suryawan, 2014).

$$
\text { Krulik dan Rudnick (1996) }
$$

menyatakan bahwa MP3M merupakan model pembelajaran yang dibangun oleh konsep-konsep:

(1) masalah,

pemecahan masalah, dan (3) penalaran. Masalah merupakan suatu situasi yang mengkonfrontasikan individu atau kelompok untuk menemukan jawaban tetapi belum mengetahui secara langsung apa yang harus dikerjakan untuk menyelesaikannya. Pemecahan masalah merupakan upaya peserta didik untuk menemukan jawaban masalah yang dihadapi berdasarkan pengetahuan, pemahaman, dan keterampilan yang telah dimiliki sebelumnya. Sedangkan penalaran terdiri dari: (1) basic thinking meliputi kemampuan memahami konsep, (2) critical thinking meliputi kemampuan menghubungkan, mengevaluasi aspek yang fokus pada masalah, mengumpulkan dan mengorganisasikan informasi, menentukan jawaban yang rasional, dan menganalisis serta mengadakan refleksi, dan (3) creative thinking meliputi kemampuan menghasilkan solusi yang original dan kemampuan melakukan generalisasi dari permasalahan yang diberikan. Dengan ketiga karakteristik dari MP3M ini, tentunya pembelajaran matematika mampu memfasilitasi siswa untuk mengembangkan kemampuan pemahaman konsep yang lebih baik.

Model pembelajaran penalaran dan pemecahan masalah memberikan kesempatan kepada siswa untuk menemukan konsep-konsep matematika melalui langkah-langkah pembelajaran yang dimuat dalam model pembelajaran ini. Melalui langkah-langkah pembelajaran tersebut nantinya siswa akan dihantarkan pada penemuan konsep-konsep matematika, serta mengorganisasikan mereka untuk menyelesaikan permasalahan yang dihadapi. Model pembelajaran penalaran dan pemecahan masalah memiliki lima langkah pembelajaran, antara lain: (1) membaca dan berpikir, yaitu mengidentifikasi fakta dan pertanyaan terkait dengan permasalahan yang diberikan, mengeksplorasi dan merencanakan, yaitu mengorganisasikan informasi dari berbagai sumber belajar untuk menyelesaikan masalah yang diberikan, (3) memilih strategi, yaitu memilih strategi yang sesuai dengan permasalahan yang diberikan, (4) menemukan jawaban, yaitu melaksanakan strategi yang dipilih, siswa dapat melaksanakan strategi yang dipilih menggunakan keterampilan komputasi, aljabar, atau geometri, dan (5) refleksi dan generalisasi, yaitu mengoreksi jawaban dan melakukan generalisasi dari masalah yang dihadapi. Menurut Krulik dan Rudnick (1996), langkah-langkah pembelajaran tersebut dapat mengorganisasikan usaha siswa dalam memahami konsep matematika sehingga pola pikir siswa lebih sistematis. Penerapan MP3M tidak hanya berorientasi pada jawaban akhir, tetapi bagaimana jawaban itu diperoleh. Dalam penerapan MP3M disajikan permasalahanpermasalahan untuk memancing kreativitas berpikir siswa.

Berdasarkan langkah-langkah dalam pembelajaran MP3M, dapat diperoleh gambaran bahwa pengintegrasian pemecahan masalah dalam setiap pembelajaran matematika memiliki peranan penting, yaitu meningkatkan kompetensi penalaran siswa, sehingga siswa lebih cermat dan analitis mengambil keputusan pada setiap permasalahan yang dihadapi, hal ini berakibat pada kemampuan pemahaman konsep matematika siswa. Hal ini didukung oleh penelitian Suarsini, dkk (2013), pada penelitian yang berjudul "Pengaruh Model Pembelajaran Reasoning and Problem Solving terhadap Hasil Belajar Matematika Siswa Kelas V SD di Gugus VIII Kecamatan Ubud" yang menyatakan bahwa penarapan Model Pembalajaran Penalaran dan Pemecahan Masalah dengan istilah lain Reasoning and Problem Solving ini dapat meningkatkan hasil belajar matematika siswa. Hasil belajar matematika yang baik didapat dari kemampuan pemahaman konsep matematika yang baik.

Namun hasil penelitian Suarsini, dkk (2013) tersebut hanya terbatas pada hasil belajar siswa yang menggunakan alat ukur yang belum mampu melihat apakah siswa memang sudah memahami konsep dengan baik atau belum. Instrumen yang digunakan 
untuk mengukur hasil belajar tentu berbeda dengan instrumen yang digunakan untuk mengukur kemampuan pemahaman konsep. Selain itu penelitian tersebut dilaksanakan pada jenjang sekolah dasar yang materi pelajarannya masih terbatas pada konsep-konsep yang sederhana dengan kemampuan pemecahan masalah siswa yang tidak terlalu tinggi. Alangkah tidak bijaksana jika Model Pembelajaran Penalaran dan Pemecahan Masalah (MP3M) ini begitu saja diterapkan pada jenjang yang lebih tinggi. Oleh sebab itu, diperlukan kajian lanjut terkait Model Pembelajaran Penalaran dan Pemecahan Masalah (MP3M) terhadap kemampuan pemahaman konsep matematika siswa pada jenjang yang lebih tinggi.

Berdasarkan uraian tersebut di atas, peneliti tertarik dan memandang perlu untuk mengadakan penelitian eksperimen dengan menerapkan MP3M terhadap kemampuan pemahaman konsep matematika siswa. Adapun penelitian ini berjudul "Pengaruh Penerapan Model Pembelajaran Penalaran dan Pemecahan Masalah (MP3M) terhadap Kemampuan Pemahaman Konsep Matematika Siswa Kelas VIII SMP Negeri 6 Singaraja".

Berdasarkan latar belakang masalah yang telah diuraikan, dapat diperoleh sebuah rumusan masalah sebagai berikut. "Apakah kemampuan pemahaman konsep matematika siswa yang dibelajarkan dengan MP3M lebih baik daripada kemampuan pemahaman konsep matematika siswa yang mengikuti pembelajaran konvensional?".

Tujuan dari penelitian ini adalah untuk mengetahui apakah kemampuan pemahaman konsep matematika siswa yang dibelajarkan dengan MP3M lebih baik daripada kemampuan pemahaman konsep matematika siswa yang mengikuti pembelajaran konvensional.

\section{METODE}

Penelitian ini merupakan penelitian eksperimen semu karena peneliti tidak mengontrol semua variabel dan kondisi eksperimen secara ketat. Hal ini sesuai dengan pernyataan Sugiyono (2012) yaitu,
"Penelitian eksperimen semu dapat dilakukan untuk melihat pengaruh yang ditimbulkan dan perlakuan berbeda yang diberikan pada masing-masing kelompok, dimana peneliti tidak mengontrol semua variabel dan kondisi eksperimen secara ketat".

Populasi dalam penelitian ini adalah seluruh siswa kelas VIII Non Unggulan SMP Negeri 6 Singaraja semester genap tahun ajaran 2016/2017 yang berjumlah 293 siswa yang tersebar ke dalam 10 kelas yaitu kelas VIII B1 sampai dengan kelas VIII B10.

Penentuan sampel dalam penelitian ini dilakukan dengan teknik cluster random sampling yaitu sampel diambil dari kelompok-kelompok kelas secara acak karena tidak memungkinkan melakukan pengacakan individu sehingga menggunakan kelas yang sudah ada.

Sebelum dilakukan penentuan sampel, terlebih dahulu dilakukan penyetaraan terhadap populasi untuk mengetahui ada tidaknya perbedaan ratarata skor kemampuan awal matematika siswa dengan menggunakan uji ANAVA satu jalur. Data yang digunakan dalam pengujian kesetaraan kelas dalam populasi adalah nilai ulangan akhir semester matematika siswa semester ganjil tahun ajaran 2016/2017.

Sebelum diuji kesetaraannya menggunakan uji ANAVA satu jalur, terlebih dahulu diuji normalitas sebaran datanya dan homogenitas variansnya. Uji normalitas sebaran data populasi menggunakan Uji Lilliefors. Setelah dianalisis, dapat disimpulkan bahwa data nilai ulangan akhir semester matematika siswa dari kesepuluh kelas tersebut dalam populasi berdistribusi normal. Kemudian setelah uji normalitas, dilanjutkan dengan uji homogenitas menggunakan uji Bartlet. Hasil yang diperoleh adalah data nilai akhir semester matematika siswa di kesepuluh kelas dalam populasi memiliki varians yang homogen.

Selanjutnya dilakukan perhitungan untuk menguji kesetaraan populasi menggunakan uji ANAVA satu jalur (Uji F) Hasil uji kesetaraan dengan menggunakan uji ANAVA satu jalur yang diperoleh $F_{\text {hitung }}=$ 0,0083 Adapun nilai $F_{\text {tabel }}$ dengan $\mathrm{dk}$ pembilang $=10-1=9$ dan $\mathrm{dk}$ penyebut $=$ 
$293-10=283$, pada taraf signifikasi 0,05 adalah 1,9130. Apabila dibandingkan, nilai $F_{\text {hitung }}$ lebih kecil dari nilai $F_{\text {tabel }}$ atau $F_{\text {hitung }}<$ $F_{\text {tabel. }}$ Maka kesepuluh kelas dalam populasi tersebut setara.

Dari kelas-kelas yang setara tersebut akan dilakukan pengambilan secara acak dengan sistem pengundian. Cara pengambilan kelas sampel dengan sistem undian adalah dua kelas yang muncul dalam undian menjadi sampel penelitian. Selanjutnya, dua kelas muncul yang diundi kembali untuk menentukan kelompok eksperimen dan kelompok kontrol dimana terpilih kelas VIII B7 sebagai kelas eksperimen dan VII B9 sebagai kelas kontrol.

Penelitian ini melibatkan variabel bebas (independent variable) dan variabel terikat (dependent variable). Adapun variabel bebas dalam penelitian ini adalah Model Pembelajaran Penalaran dan Pemecahan Masalah (MP3M) pada kelompok eksperimen dan pembelajaran konvensional pada kelompok control sedangkan variabel terikatnya adalah kemampuan pemahaman konsep matematika siswa.

Rancangan yang digunakan dalam penelitian ini adalah "Post Test Only Control Group Design" . Terdapat dua kelompok yang menjadi sampel penelitian yaitu kelompok eksperimen dan kelompok kontrol.

Instrumen yang digunakan dalam penelitian ini berupa tes. Data yang akan dikumpulkan pada penelitian ini berupa kemampuan pemahaman konsep matematika siswa, yang dikumpulkan melalui tes kemampuan pemahaman konsep matematika. Tes kemampuan pemahaman konsep matematika yang akan digunakan adalah tes uraian. Digunakannya tes uraian ini dengan alasan dapat diketahui bagaimana siswa menyatakan konsep dengan kata-kata sendiri, mengidentifikasi contoh dan bukan contoh dari suatu konsep, dan menuangkan pemikirannya secara tertulis terhadap jawaban dari permasalahan yang diberikan. Untuk memudahkan dalam pemeriksaan dan meminimalisir subjektivitas, dibuat rubrik penskoran untuk tes kemampuan pemahaman konsep matematika siswa. Pada penelitian ini rubrik yang digunakan adalah dari NCTM pada tahun 2000.

Setelah instrumen tersusun, maka dilakukan uji coba instrumen yang selanjutnya dianalisis dengan uji validitas dan uji reliabilitas. Sebelum di uji cobakan, peneliti menguji instrumen pada judgment untuk mengetahui validitas isi instrumen.

Untuk menguji validitas butir soal uraian digunakan koefisien korelasi product-moment dari Carl Pearson (Candiasa, 2011:38).

Ujicoba validitas isi tes ini dilakukan dengan meminta bantuan dua orang dosen di lingkungan Jurusan Pendidikan Matematika yang ahli dalam bidang assesment. Uji coba penelitian ini dilakukan di kelas VIIIA SMP Negeri 7 Singaraja. Dimana jumlah soal yang diujicobakan adalah tujuh butir soal. Dari hasil uji coba validitas tes diperoleh tujuh buah soal yang valid. ketujuh soal tersebut diuji reliabilitasnya. Melalui perhitungan diperoleh bahwa $r_{11}=0,7630$ dimana dari kriteria yang telah ditetapkan maka derajat reliabilitas tes tergolong tinggi.

Sebelum dilaksanakan pengujian untuk memperoleh simpulan, data yang diperoleh harus diuji normalitasnya. Uji normalitas untuk skor kemampuan pemahaman konsep matematika siswa digunakan teknik Lilliefors. Pada pengujian normalitas data dengan teknik Lilliefors, dicari selisih frekuensi sebaran data dengan frekuensi kumulatif sampai batas tiap-tiap data.

Uji homogenitas varians untuk kedua kelompok digunakan $\mathrm{Uji} F$ dengan menggunakan rumus sebagai berkut:

$$
\mathrm{F}_{\text {Hitung }}=\frac{S_{1}^{2}}{S_{2}^{2}}
$$

Setelah diuji normalitas dan homogenitas data selanjutnya akan dilakukan uji hipotesis penelitian. Karena terbukti bahwa data berdistribusi normal dan homogen maka untuk menguji hipotesis nol digunakan uji-t dengan taraf signifikansi $5 \%$ yang dirumuskan 


$$
t_{h i t}=\frac{\bar{Y}_{1}-\bar{Y}_{2}}{\sqrt{\frac{s^{2}}{n_{1}}+\frac{s^{2}}{n_{2}}}}
$$

dengan:

$$
\begin{aligned}
& s^{2}=\frac{\left(n_{1}-1\right) s_{1}^{2}+\left(n_{2}-1\right) s_{2}^{2}}{\left(n_{1}+n_{2}-2\right)} \\
& s_{1}^{2}=\frac{\sum\left(X_{i}-\bar{X}_{1}\right)^{2}}{n_{1}-1} \quad ; \quad s_{2}^{2}=\frac{\sum\left(X_{i}-\bar{X}_{2}\right)^{2}}{n_{2}-1}
\end{aligned}
$$

(Candiasa, 2010:58)

\section{HASIL DAN PEMBAHASAN}

Data mengenai skor kemampuan pemahaman konsep matematika siswa diperoleh dari post-test yang diberikan kepada kedua kelompok sampel dapat dilihat pada tabel 1 berikut. konvensional maka perlu dilakukan pengujian terhadap $\mathrm{H}_{0}$. Sebelum uji hipotesis dilakukan, terlebih dahulu dilakukan pengujian terhadap normalitas dan homogenitas varians skor tes kemampuan pemahaman konsep matematika siswa.

Hasil uji normalitas data kemampuan pemahaman konsep matematika siswa pada kelas kontrol diperoleh $L_{\text {hitung }}=$ 0,1278 (untuk $\mathrm{dk}=\mathrm{n}=29$ pada taraf signifikansi 5\%) diperoleh $L_{\text {tabel }}=0,1645$.

Karena $L_{\text {hitung }}<L_{\text {tabel }}$, maka sebaran data
kemampuan pemahaman konsep
matematika siswa pada kelas kontrol
berdistribusi normal. Sedangkan, hasil uji
normalitas data kemampuan pemahaman
konsep matematika siswa pada kelas
eksperimen diperoleh $L_{\text {hitung }}=0,1477$
(untuk $\mathrm{dk}=\mathrm{n}=29$ pada taraf signifikansi

Tabel 1. Rangkuman analisis data skor kemampuan pemahaman konsep matematika siswa

\begin{tabular}{|c|cc|}
\hline \multirow{2}{*}{ Variabel } & \multicolumn{2}{|c|}{ Sampel } \\
\cline { 2 - 4 } & Kelas Eksperimen & Kelas Kontrol \\
\hline Banyak Siswa $(\mathrm{N})$ & 29 & 29 \\
Rata-rata skor $(X)$ & 28,4138 & 23,2069 \\
\hline Standar Deviasi $(\mathrm{SD})$ & 8,4562 & 6,5351 \\
\hline
\end{tabular}

Berdasarkan tabel 1 tersebut terlihat bahwa rata-rata skor kemampuan pemahaman konsep matematika siswa pada kelas eksperimen lebih tinggi daripada rata-rata skor kemampuan pemahaman konsep matematika siswa kelas kontrol.

Untuk mengetahui apakah kemampuan pemahaman konsep matematika siswa yang mengikuti Model Pembelajaran Penalaran dan Pemecahan
$5 \%$ diperoleh $L_{\text {tabel }}=0,1645$. Karena $L_{\text {hitung }}<L_{\text {tabel }}$, maka sebaran data kemampuan pemahaman konsep matematika siswa pada kelas eksperimen berdistribusi normal. Jadi dapat disimpulkan kedua kelas sampel beridistribusi normal.

Selanjutnya dilakukan uji homogenitas menggunakan Uji - F. Hasil uji homogenitas varians sebaran data skor kemampuan pemahaman konsep

Tabel 2. Rangkuman hasil uji Homogenitas varians skor pemahaman konsep matematika siswa

\begin{tabular}{|c|c|c|c|c|}
\hline $\begin{array}{c}\text { Kelompok } \\
\text { Sampel }\end{array}$ & Varinas & $F_{\text {hitung }}$ & $F_{\text {tabel }}$ & Keterangan \\
\hline Eksperimen & 65,3941 & 1,6136 & 2,1299 & Homogen \\
\hline Kontrol & 40,5271 & 1,613 & \\
\hline
\end{tabular}

Masalah (MP3M) lebih baik daripada kemampuan pemahaman konsep matematika yang mengikuti pembelajaran matematika siswa untuk kedua kelompok dapat dilihat pada tabel 2 berikut. 
Dari tabel 2 tersebut, dapat dilihat bahwa Fhitung lebih kecil darpada $F_{\text {tabel. }}$ Dengan demikian $\mathrm{H}_{0}$ diterima dan hal tersebut berarti data kemampuan pemahaman konsep matematika siwa pada kelas sampel mempunyai varians yang homogen.

$$
\text { Pengujian normalitas dan }
$$

homogenitas menunjukkan bahwa data sampel memiliki sebaran data yang normal dan memiliki varians yang homogen sehingga untuk menguji hipotesisnya digunakan uji-t satu ekor. Hasil perhitungan diperoleh nilai $t_{\text {hitung }}$ adalah 2,7245 dan nilai $t_{\text {tabel }}$ adalah 1,6725. Apabila dibandingkan, nilai $t_{\text {hitung }}$ lebih dari nilai $t_{\text {tabel }}$. Dengan demikian $\mathrm{H}_{0}$ ditolak. Hal ini berarti kemampuan pemahaman konsep matematika siswa yang mengikuti Model Pembelajaran Penalaran dan Pemecahan Masalah (MP3M) lebih baik daripada kemampuan pemahaman konsep matematika siswa yang mengikuti pembelajaran konvensional.

Hasil analisis terhadap skor kemampuan pemahaman konsep matematika siswa terhadap dua kelas sampel yakni kelas eksperimen dan kontrol menunjukkan bahwa rata-rata skor kemampuan pemahaman konsep matematika siswa pada kelas eksperimen lebih tinggi daripada rata-rata skor kemampuan pemahaman konsep matematika siswa kelas kontrol. Untuk kelas eksperimen, rata-rata skor kemampuan pemahaman konsep matematika siswa adalah 28,4138, sedangkan rata-rata skor kemampuan pemahaman konsep matematika siswa kelas kontrol adalah 23,2069. Selanjutnya, hasil pengujian hipotesis data skor kemampuan pemahaman konsep matematika siswa terhadap dua kelas yakni kelas eksperimen dan kontrol di mana karena kedua sampel berdistribusi normal dan variansnya homogen, maka diuji dengan uji- $t$ ekor kanan dan diperoleh kesimpulan bahwa kemampuan pemahaman konsep matematika siswa yang mengikuti pembelajaran dengan Model Pembelajaran Penalaran dan Pemecahan Masalah (MP3M) lebih baik daripada kemampuan pemahaman konsep matematika siswa yang mengikuti pembelajaran konvensional. Hal ini dikarenakan Siswa yang mengikuti pembelajaran dengan Model Pembelajaran Penalaran dan Pemecahan Masalah (MP3M) menjawab permasalahan secara lebih terstruktur dibandingkan dengan siswa yang mengikuti pembelajaran konvensional. Pembelajaran dengan Model Pembelajaran Penalaran dan Pemecahan Masalah (MP3M) lebih memberikan siswa kesempatan berpartisipasi dalam menyelesaikan suatu masalah untuk menemukan suatu konsep sehingga siswa lebih tahu letak-letak kesalahan yang sering dilakukan dalam menyelesaikan suatu permasalahan. Latihan-latihan untuk menyelesaikan masalah membantu meningkatkan kemampuan pemahaman konsep matematika siswa.

MP3M terdiri dari 5 tahapan yaitu membaca dan berpikir, mengeksplorasikan dan merencanakan, memilih strategi, menemukan jawaban, dan refleksi dan generalisasi. Masing-masing tahapan tersebut akan dapat membantu siswa untuk membangun sendiri pemahamannya terhadap apa yang sedang mereka pelajari. Pada tahap membaca dan berpikir, guru memberikan permasalahan kepada siswa berupa LKS (Lembar Kerja Siswa) selanjutnya siswa diberikan kesempatan untuk membaca dan berpikir bersama anggota kelompoknya. Melalui penyajian masalah ini guru dapat melatih siswa untuk memahami beragam permasalahan sehingga siswa tahu apa yang harus diperolehnya selama pembelajaran untuk menyelesaikan masalah, kemudian siswa menuangkan dengan kata-kata sendiri serta dapat mengidentifikasi contoh dan bukan contoh dari topik.

Pada tahap mengeksplorasi dan merencanakan, siswa telah memahami permasalan yang diberikan. Melalui tahapan ini siswa dilatih untuk mengembangkan pengetahuan yang dimiliki, dan membuat rencana penyelesaian masalah. Kemampuan yang harus dimiliki siswa untuk dapat membuat suatu perencanaan, tentu siswa harus dapat memahami konsep dengan caranya sendiri. 
Pada tahap memilih strategi, siswa memilih strategi atau menerapkan konsep yang sesuai dengan situasi permasalahan yang diberikan. Pemilihan strategi atau penerapan konsep yang tepat ini berdasarkan pada kemampuan siswa dalam usaha memahami konsep dengan caranya sendiri, berdasarkan pengalaman penyelesaian masalah.

Pada tahap menemukan jawaban, siswa melaksanakan rencana penyelesaian masalah sesuai dengan strategi atau konsep yang telah dipilih pada tahap sebelumnya. Pada tahap ini, siswa harus memiliki kemampuan dalam mengaplikaskan atau menggunakan konsep dengan benar dalam berbagai situasi permasalahan yang diberikan oleh guru.

Pada tahap refleksi dan generalisasi, salah satu kelompok mempresentasikan hasil diskusi, kemudian kelompok lainnya melakukan refleksi dan pengembangan seperti memantau prosedur penyelesaian masalah yang telah dilakukan, jika ada jawaban yang keliru atau adanya perbedaan jawaban antaran kelompok yang satu dengan yang lainnya, maka didiskusikan kembali hingga mencapai suatu jawaban yang benar.

$$
\text { Dengan penerapan Model }
$$

Pembelajaran Penalaran dan Pemecahan Masalah (MP3M) siswa terlatih untuk menyelesaiakan masalah matematika dengan konsep yang benar, hal ini berpengaruh positif terhadap kemampuan pemahaman konsep matematika siswa.

Ini sejalan dengan penelitian I Putu Pasek Suryawan (2014) yang menyatakan bahwa penerapan Model Pembelajaran Penalaran dan Pemecahan Masalah (MP3M) berorientasi masalah terbuka menunjukkan aktivitas siswa yang tinggi sehingga dapat meningkatkan prestasi belajar matematika siswa. Penelitian ini memiliki hasil yang sesuai dengan penelitian Suarsini, dkk (2013) yang telah melaksanakan penelitian lebih dulu, bahwa hasil belajar akan mempengaruhi prestasi belajar dari siswa. Meningkatkan hasil dan prestasi belajar matematika siswa didasari oleh adanya peningkatan kemampuan pemahaman konsep matematika siswa. Hal ini disebabkan oleh, kemampuan pemahaman konsep matematika merupakan kemampuan dasar yang harus dimiliki siswa untuk dapat menguasai kemampuan yang lainnya. Didukung oleh pendapat Benyamin S.Bloom (dalam Hamalik, 2001) menyatakan prestasi belajar merupakan hasil perubahan perilaku yang meliputi ranah kognitif, afektif, dan psikomotor. Dengan ranah kognitif terdiri atas : pengetahuan, pemahaman, aplikasi, analisis, sintesis, dan evaluasi. Sehingga, kemampuan merupakan salah satu penunjang keberhasilan prestasi belajar siswa. Dengan demikian, siswa yang dibelajarkan dengan Model Pembelajaran Penalaran dan Pemecahan Masalah (MP3M) dapat meningkatkan kemampuan pemahaman konsep matematika siswa.

Ditinjau dari hasil analisis terhadap hasil tes kemampuan pemahaman konsep matematika siswa menunjukkan bahwa siswa yang mengikuti pembelajaran dengan Model Pembelajaran Penalaran dan Pemecahan Masalah (MP3M) mampu menyelesaikan permasalahan matematika dengan konsep yang benar dibandingkan dengan siswa yang mengikuti pembelajaran dengan pembelajaran konvensional karena dengan menerapkan Model Pembelajaran Penalaran dan Pemecahan Masalah (MP3M), siswa terbiasa menemukan jawaban sendiri dan mandiri dalam memahami materi.

Secara umum, pelaksanaan pembelajaran dengan Model Pembelajaran Penalaran dan Pemecahan Masalah (MP3M) dapat berjalan baik dan sesuai rencana. Walaupun demikian, dalam pelaksanaannya di kelas tidak luput dari adanya kendala-kendala. Adapun kendalakendala yang dihadapi adalah sebagai berikut.

1. Memerlukan manajemen waktu yang baik dalam persiapan maupun pelaksanaan proses pembelajaran dengan menggunakan Model Pembelajaran Penalaran dan Pemecahan Masalah (MP3M). Hal ini karena siswa harus mengumpulkan informasi sendiri dari berbagai sumber untuk menyelesaiakan permasalahan yang diberikan. Pengumpulan 
informasi tersebut memerlukan waktu yang banyak.

2. Siswa merasa kebingungan saat model ini pertama kali diterapkan sehingga siswa memerlukan waktu untuk terbiasa. Oleh karena itu, diperlukan upaya ekstra diawal pembelajaran agar maksud model pemebalarajan dapat dipahami siswa.

Namun kendala-kendala tersebut dapat ditangani dengan baik. Pada awalawal pertemuan memang sulit, namun seiring berjalannya waktu pada pertemuan selanjutnya siswa sudah terbiasa dengan penerapan Model Pembelajaran Penalaran dan Pemecahan Masalah (MP3M).

Berdasarkan hasil pengujian hipotesis di atas, dapat dilihat bahwa pembelajaran dengan Model Pembelajaran Penalaran dan Pemecahan Masalah (MP3M) berpengaruh positif terhadap kemampuan pemahaman konsep matematika siswa. Hal ini dibuktikan dengan hasil post-test yang menunjukkan bahwa kemampuan pemahaman konsep matematika siswa yang mengikuti pembelajaran dengan Model Pembelajaran Penalaran dan Pemecahan Masalah (MP3M) lebih baik daripada siswa yang mengikuti pembelajaran konvensional.

\section{SIMPULAN DAN SARAN}

Berdasarkan uraian pada hasil penelitian dan pembahasan, dapat disimpulkan bahwa kemampuan pemahaman konsep matematika siswa yang mengikuti pembelajaran dengan Model Pembelajaran Penalaran dan Pemecahan Masalah (MP3M) lebih baik daripada kemampuan pemahaman konsep matematika siswa yang mengikuti pembelajaran konvensional. Jadi, pembelajaran matematika dengan Model Pembelajaran Penalaran dan Pemecahan Masalah (MP3M) memberikan pengaruh positif terhadap kemampuan pemahaman konsep matematika siswa.

Berdasarkan hasil penelitian yang diperoleh, peneliti melalui tulisan ini mengajukan beberapa saran. Adapun saran-saran yang dapat disampaikan adalah sebagai berikut: kepada praktisi pendidikan khususnya guru, disarankan untuk menggunakan Model Pembelajaran Penalaran dan Pemecahan Masalah (MP3M) sebagai salah satu alternatif model pembelajaran matematika terutama apabila ingin meningkatkan kemampuan pemahaman konsep matematika siswa.

Kepada peneliti yang tertarik untuk melaksanakan penelitian lebih lanjut mengenai Model Pembelajaran Penalaran dan Pemecahan Masalah (MP3M), disarankan untuk melakukan penelitian terhadap pembelajaran ini dengan populasi yang lebih besar dan materi pembelajaran yang lebih luas untuk mengetahui pengaruh pembelajaran ini dalam pembelajaran matematika secara lebih mendalam. Dalam melakukan penelitian menggunakan Model Pembelajaran Penalaran dan Pemecahan Masalah (MP3M) diharapkan agar memperhatikan kekurangan atau kelemahan model ini sebagai bahan pertimbangan untuk perbaikan dan penyempurnaan pelaksanaan penelitian selanjutnya.

\section{DAFTAR PUSTAKA}

Ardana, Made dkk. 2008. "Peningkatan Kualitas Belajar Siswa Melalui Pengembangan Pembelajaran Matematika Berorientasi Gaya Kognitif dan Berwawasan Konstruktivis". Jurnal Penelitian dan Pengembangan Pendidikan, Lembaga Penelitian Undiksha, April 2008. (1), 1-14.

Candiasa, I Made.2010. Statistik Univariat dan Bivariat Disertai Aplikasi SPSS. Singaraja : Unit Penerbitan Universitas Pendidikan Ganesha.

2011. Pengujian Instrumen
Penelitian Disertai Aplikasi
ITEMAN dan BIGSTEP. Singaraja
$:$ Unit Penerbitan Universitas
Pendidikan Ganesha.

Depdiknas. 2006. Permen 23 Th.2006Standar Isi, Standar Kompetensi dan Kompetensi Dasar Matematika SMP. Jakarta: Dirjen Manajemen 
Pendidikan Dasar dan Menengah, Diknas.

Hamalik, Oemar. 2001. Proses Belajar Mengajar. Bandung :Bumi Aksara.

Hanifah. 2016. "Pengaruh Pendekatan Saintifik terahadap Keterampilan Proses Sains dan Hasil Belajar Kognitif Siswa Kelas VII SMP Negeri 2 Berbah. Tersedia : http://eprints.uny.ac.id/32629/2/BA B\%20I.pdf [diakses 21 Juni 2017]

Krulik, S.,\& Rudnick, J.A. 1996. The New Sourcebook For Teaching Reasoning and Problem Solving in Junior and High School. Boston: Allyn and Bacon.

NCTM. 2000. Mathematics Assessment a Practical Handbook for Grades 68. United States of America: NCTM.

Ni Wayan Suarsini, I Dw. Kade Tastra, dan Md. Suarjana. 2013. "Pengaruh Model Pembelajaran Reasoning and Problem Solving terhadap Hasil Belajar Matematika Siswa Kelas V SD di Gugus VIII Kecamatan Ubud". Singaraja : Universitas Pendidikan Ganesha

Sugiyono. 2012. Memahami Penelitian Kualitatif. Bandung. ALFABETA

Suherman, Erman 2003. Strategi Pembelajaran Matematika Kontemporer. Universitas Pendidikan Indonesia

Suryawan, Pasek. 2014. "Pengembangan Perangkat Pembelajaran Matematika Untuk Model Pembelajaran Penalaran Dan Pemecahan Masalah (MP3M) Berorientasi Masala Terbuka". Jurnal Wahana Matematika dan Sains, Volume 8, Nomor 1, April 2014, hlm 26-44

Trianto. 2011. Model Pembelajaran Terpadu Konsep, Strategi dan Implementasinya dalam Kurikulum Tingkat Satuan Pendidikan (KTSP). Jakarta : Bumi Aksara
Zulkardi. 2003. "Pendidikan Matematika Republik Indonesia". Tersedia : http://pmri.or.id/ [diakses 29 Pebruari 2017] 